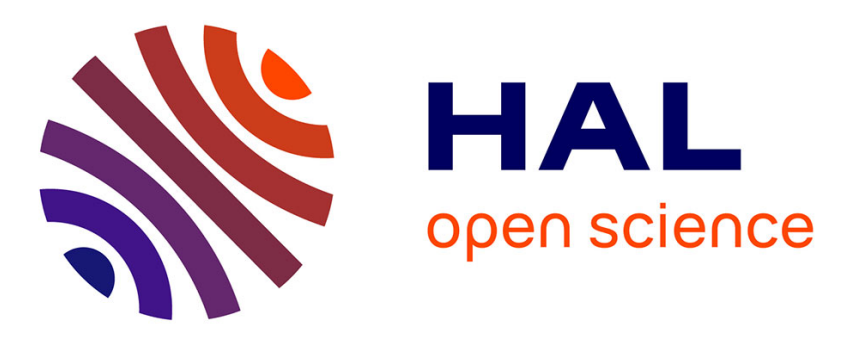

\title{
Determination of annual reproductive cycle in male sterlet, Acipenser ruthenus using histology and ultrasound imaging
}

Amin Golpour, Coralie Broquard, Sylvain Milla, Hadiseh Dadras, Abdul Rasheed, Taiju Saito, Martin Psenicka

\section{To cite this version:}

Amin Golpour, Coralie Broquard, Sylvain Milla, Hadiseh Dadras, Abdul Rasheed, et al.. Determination of annual reproductive cycle in male sterlet, Acipenser ruthenus using histology and ultrasound imaging. Fish Physiology and Biochemistry, 2020, 10.1007/s10695-020-00892-8 . hal-03069667

\section{HAL Id: hal-03069667 https://hal.science/hal-03069667}

Submitted on 15 Dec 2020

HAL is a multi-disciplinary open access archive for the deposit and dissemination of scientific research documents, whether they are published or not. The documents may come from teaching and research institutions in France or abroad, or from public or private research centers.
L'archive ouverte pluridisciplinaire HAL, est destinée au dépôt et à la diffusion de documents scientifiques de niveau recherche, publiés ou non, émanant des établissements d'enseignement et de recherche français ou étrangers, des laboratoires publics ou privés. 
Determination of annual reproductive cycle in male sterlet, Acipenser ruthenus using histology and ultrasound imaging

1Amin Golpour, 2 Coralie Broquard, 2 Sylvain Milla, 1Hadiseh Dadras, 1Abdul Rasheed Baloch 1Taiju Saito, 1Martin Pšenička

1Faculty of Fisheries and Protection of Waters, South Bohemian Research Center of Aquaculture and Biodiversity of Hydrocenoses, Research Institute of Fish Culture and Hydrobiology, University of South Bohemia in České Budějovice, Vodňany, Czech Republic

2 University of Lorraine, Boulevard des Aiguillettes, BP 236, 54506, Vandoeuvre-Les-Nancy, France. 


\begin{abstract}
The aim of this study was to evaluate seasonal testicular development in the cultured sterlet, Acipenser ruthenus. During annual sexual cycle of male sterlet, stages of gonad maturity were examined using histology and ultrasonography approaches. The histology identified males at different stages of maturity among fish sampled monthly. According to the seasonal changes in the testes, reproductive cycle was divided into four stages including resting, pre-spawning, spawning and post-spawning. The histology examination revealed considerable variation in testicular developmental stages. These changes were identified based on persistent spermatogenesis and asynchronous gonad development in testes, showing regulation of annual gonadal cycle is influenced by season. Also, the results obtained using ultrasound suggested that reproductive stages can be identified based on morphology and tissue echogenicity. At each phase of testicular development, gonadosomatic index (GSI) and number of spermatogenic cysts were variable. The present study focused on determination of annual reproductive development in cultured male sterlet which clearly identifies reproductive stage in each season as valuable guide for future researches on reproductive biology of sterlet. This study presents basic knowledge about reproductive biology in sterlet contributing to optimal broodstocks management that allows comparison of reproductive development among sturgeon species.
\end{abstract}

Key words: Breeding season; Reproductive cycle; Spermatogenesis; Sterlet; Testicular development

\title{
Introduction
}

In studies on annual gonadal cycle of fish, it is crucial to examine gonadal cycle and spawning pattern (Tan-Fermin et al., 1997; Manosroi et al., 2003; Golpour et al., 2016a. 2017; Niksirat et al., 2017). Several studies have already carried out regarding the artificial reproduction of wild sterlet fish (Horvath et al.,1986; Williot et al., 2005); however, knowledge on the reproductive cycle either in wild population or cultured condition is limited. Only, preliminary results dealing with gonadal development in cultured sterlet have been published previously (Jackson et al., 2006). Development of staging designation in sturgeons is difficult due to the absence of morphological characteristics before sexual 
maturity, the gonad maturation cycle and the anatomical characteristics of the reproductive system (Lagler et al., 1977; Dettlaff et al., 1993; Doroshov et al., 1997). The gonadal cycles determination have been done in sturgeons including male and female of white sturgeon, Acipenser transmontanus (Doroshov et al., 1997), female siberian sturgeon, Acipenser baerii (Williot et al., 2002), male and female of amur sturgeon, Acipenser schrenckii (Qu et al., 2010), Sterlet, Acipenser ruthenus (Golpour et al., 2016b) and both sexes of shortnose sturgeon, Acipenser brevirostrum (Colombo et al., 2007). However, limited information is available on gonadal cycles and reproductive physiology of Acipenseriformes.

The determination of reproductive stages in sturgeons using diagnostic methods such as quantification of plasma sex hormones and histology have been widely used (Feist et al., 2004; Craig et al., 2009; Webb et al., 2002; Barannikova et al., 2004). However, these techniques are time consuming and harmful for small sturgeons. Additionally, other methods such as determination of stage through an incision in the body wall has also been used (Chen et al., 2011). The negative effects of these approaches on small captive broodstock cannot be ignored. Therefore, a reliable method for determination of maturity is critically needed in modern broodstock management to avoid the potential negative effects on gonads or muscles and consequently mortality. The non-invasive technique using ultrasound technology has been mostly tested for gender identification in sturgeons (Wildhaber et al., 2005; Bryan et al., 2007; Hurvitz et al., 2007; Chebanov and Galich, 2009; Divers et al., 2009). In addition, this non-invasive method is also useful to determine the maturity stage of small captive sturgeons. The sterlet, Acipenser ruthenus, is a relatively small species of sturgeon which is widely distributed in central-eastern Europe and Asia (Bemis and Kynard, 1997). Decline of natural spawning activity in its population from native habitat is mainly due to loss of spawning grounds, overfishing, poaching, and environmental pollution (Jackson et al., 2006). Various studies have already been conducted regarding the artificial reproduction of wild sterlet fish (Horvath et al., 1986; Williot et al., 2005); however, knowledge on the reproductive cycle either in wild population or cultured condition is limited. The ultrasound method has been successfully used sex determination of various sturgeon species such as stellate sturgeon Acipenser stellatus (Moghim, Vajihi, Veshkini, \& Masoudifard, 2002), shovelnose sturgeon Scaphirhynchus platorynchus (Colombo, Willis, \& Garvey, 2004) and pallid sturgeon 
Scaphirhynchus albus (Wildhaber et al., 2005). Considering above statement, this tool solely is not exclusively used for sex determination and can be useful to ascertain the reproduction status throughout the year, particularly outside of the spawning season (Blythe et al., 1994). Thus, obtaining data on gonad maturity stages using the histology and non-invasive method provide reliable information for artificial culture and restocking programs. The objectives of the study was to evaluate the usefulness of ultrasonic method to assess stages of maturity of the male's gonads in sterlet throughout the year and validate/compare the results by histological analysis.

\section{Materials and methods}

\section{Fish}

Thirty six adult males of sterlet ( $\sim 5$ years old, weight $0.76-1.24 \mathrm{~kg}$, length $52.5-64.6 \mathrm{~cm}$ ) were provided by the Fischzucht Rhönforelle GmbH \& Co. KG, Marjoss, Germany. Fish were kept in outdoor plastic tanks $(4 \mathrm{~m} 3)$ with a constant flow rate of $20 \mathrm{~L} / \mathrm{min}$ pond water at hatchery of the Research Institute of Fish Culture and Hydrobiology (Vodnany, Czech Republic).

\section{Sampling and analysis}

Gonad samples were collected from three individuals every month from July 2014 to June 2015. Gonadal samples were kept in sampling bottles and fixed in Bouin's solution. After 24 $\mathrm{hr}$, the samples were transferred into $70 \%$ ethanol and processed using the routine histological methods. Samples of gonad tissues were processed routinely by dehydration in a graded series of ethanol solutions of increasing concentration, followed by clearing in a series of xylenes solvent (three times), embedding in paraffin, and sectioning at $5 \mu \mathrm{m}$. Prepared slides were stained with hematoxylin and eosin (H\&E), and then observed under light microscope (Leica DM 750, Heerbrugg, Switzerland). The percentage of spermatogenic cells at different phases of the reproductive cycle was quantified using light microscope (Leica DM 750). The developmental stages were identified based on descriptions given by Doroshov et al. (1997). In order to perform a quantitative assessment of spermatogenic cells, at least fifteen histology photos were randomly evaluated to count number of spermatogonia (SG), spermatocytes (SC), spermatids (ST) and spermatozoa (SZ) at each phase of the 
reproductive cycle were calculated in specific number of seminiferous tubules of gonad. Ultrasound images were collected in the laboratory using a clinical portable ultrasound unit (Chison Eco 1 with a 7.5-MHz linear probe, China). Prior to scanning the body cavity of fish, the head of transducer was first covered with ultrasound gel and then, a plastic sheath was placed over the ultrasound transducer to be protected against rough contact with scutes. A right or left lateral side view of the fish between the pectoral and anal fins was obtained (Chebanov and Galich, 2009). During the scanning, constant focus, brightness and settings were used and the gained settings were fixed.

\section{Data analyses}

Computer statistical analysis was carried out using statistica software for Windows, v. 9.1 (StatSoft, Inc., Talsa, OK, USA). Data were expressed as mean \pm SD. One-way analysis of variance (ANOVA) was followed by a Tukey's test. Statistical significance was tested at the $p$ $<.05$ level.

\section{Results}

A total of 36 sterlets were examined from July 2014 to June 2015 for annual reproductive cycle assessment using histological descriptions and ultrasonography approach. Using histology, development and growth of testes during annual cycle were divided into four stages according to the different seasons. During testicular development, a variable number of spermatogenic cysts at different stages were found in each seminiferous lobule. The seasonal changes of the testes, weight, length, GSI and water temperature are presented in Table 1. The ultrasonographic images of testes in fall season (Resting phase) showed crenate and narrow with a string-like appeared testis. In addition, the gonad was contained hypoechoic fat (Figure 1a). Ultrasonographic images of sterlet testes in winter (pre-spawning phase) appeared as a smooth grey region (Figure 1b), and the images in spring (Spawning phase) were homogeneous and smooth with distinct margin and well-defined actual shape of testis (Figure 1c). The testes in summer (post-spawning phase) were found to be with smooth dark grey structures and also without any actual shape in ultrasonography images (Figure 1d).

In resting phase, ultrasonographic images revealed that testes were small and surrounded by fat tissue. Gonadosomatic index was lowest throughout the year except in pre-spawning 
phase (Table 1). Also, this phase was dominated by type A spermatogonia (93.6 $\pm 0.76 \%$ ) and few type $\mathrm{B}$ spermatogonia $(5.2 \pm 0.18 \%)$ (Figure $2 \mathrm{a}$; Table 2$)$. At the end of fall season, spermatogenesis started with proliferation of spermatogonia (Figure $2 \mathrm{~b}$ ).

In the next phase (Pre-spawning phase), the cyst was predominately occupied by spermatocytes and spermatids (Figure 3), which on average constituted $41 \pm 0.63 \%$ and $34.8 \pm 0.50 \%$ (Table 2), respectively. Furthermore, rapid increase of GSI was observed in pre-spawning phase of testis development compared to the other phases (Table 1). In spawning phase, GSI index followed a trend similar to previous months of pre-spawning phase (Table 1). In this phase, the bulged out testes in abdominal cavity appeared in white. Due to rupture of spermatogenic cyst, spermatozoa uniformly filled the lumen of seminiferous lobules. In spawning phase, spermatids and spermatozoa were dominant (Figure 4), which on average constituted $5.6 \pm 0.20 \%$ and $92.2 \pm 62 \%$ (Table 2 ), respectively. In post-spawning phase, the testes mostly were empty. Further, the leftover meiotic cells and spermatozoa were reabsorbed (Figure $5 \mathrm{a}$ and $\mathrm{b}$ ). The spermatogonia populations were found to be abundant in cyst of seminiferous tubules (Figure 5b; Table 2). Gonadosomatic index was almost similar to resting and spawning phases (Table 1). The percentage of spermatogonia and spermatozoa were $87.2 \pm 0.57 \%$ and $11.1 \pm 0.43 \%$, respectively (Table 2). In addition, 3 out of 36 males were found to have intersex gonads. The intersex gonads were typical testes with distribution of few pieces of ovary throughout each testis. All observed oocytes in intersex gonads were at the pre-vitellogenic stage (Figure 6 a,b).

\section{Discussion}

The present study revealed a seasonal pattern of gonadal development in male sterlet, with onset of testicular meiosis in fall season, and final gonadal maturation during spring. In the present study, the different seasonal water temperatures in holding tanks were associated with different patterns of gonadal development, emphasizing the importance of temperature as a major factor affecting testicular development. Using histology approach, a marked difference in the pattern of gonadal recrudescence in male sterlet was found. Spermatogenic activity was begun at the end of autumn and continued in winter, leading to the appearance of spermatozoa in lobule of lumen in early spring. In sampled testes from January onward, 
different spermatogenic cells were appeared and developed spermatozoa were observed frequently. We identified four stages of gonad development coinciding with those stages identified in different sturgeon species (Doroshov et al., 1997; Flynn and Benfey, 2007; Matsche et al., 2013; Qu et al., 2010). Further, a similar pattern of gonadal development and maturation of gonad has been observed in green sturgeon Acipenser medirostris (Reviewed by Alavi et al., 2010). It is also noteworthy to note that, all three sterlets with intersex gonads founded in the present study were contained small female gonad portions (testes-ova). Occurrence of this phenomenon has been also observed in several sturgeons including shortnose sturgeon A. brevirostrum (Williot et al., 2005; Henne et al., 2006), Russian sturgeon Acipenser gueldenstaedtii (Jackson et al., 2006), and sterlet Acipenser ruthenus (Williot et al., 2005). This amount of intersexuality is consistent with the rate of $1 \%$ reported in Atlantic sturgeon Acipenser oxyrinchus (Van Eenennaam et al., 1996), Russian sturgeon Acipenser gueldenstaedtiiand and Siberian sturgeon Acipenser baerii (Rzepkowska et al., 2014).

In the present study, the different seasonal water temperatures in holding tanks were associated with four phases of gonadal development, emphasizing the importance of temperature as a major factor affecting testicular development. Ultrasound imaging has been successfully used to determine gender and maturity of different adult sturgeons including Chinese sturgeon Acipenser sinensis (Wildhaber et al., 2005; Du et al., 2017), shovelnose sturgeon Scaphirhynchus platorynchus (Colombo et al., 2007), beluga sturgeon Huso huso (Masoudifard et al., 2011) and sturgeon hybrids Acipenser naccarii $\times$ Acipenser baerii (Petochi et al., 2011) at different reproductive stages. In this context, some descriptions of ultrasonic images have been used for better characterization of fish gonad (Jennings et al., 1996; Bryan et al., 2007). The ultrasound imaging also can be used to determine some parameters such as size of the ovary or testis and gonad shape (Albers et al., 2013). However, some other parameters including fecundity and GSI might be determined via further analyses (Bryan et al., 2007). In some cases, application of ultrasound is not useful to characterize gonad stages, particularly in immature male sturgeons, due to the small gonads. In a study on Chinese Sturgeon, two sets of characterizations (i.e proportion of the gonad to the whole reproductive organs and thickness of the reproductive organs) using ultrasound were applied 
for sexing and determining sexual maturity stage (Du et al., 2017). However, to date, no study has noted that ultrasound can be used determine the stage of maturity based on size of testicular tissue (Webb et al., 2017). Similar to our methodology and results, the density of testicular tissue observed on a sonogram as shades of white is being examined as an indicator of maturity stage (Webb et al., 2017). Considering other parameters of ultrasonography except morphological characteristics, however might be beneficial to determine errors associated with development of less invasive techniques.

The present information suggests a valuable guideline for seasonal gonad differentiation and sexual maturity in male sterlet. Our findings provide useful data for commercial purposes of propagation and comparison of reproductive development among sturgeon species.

\section{Acknowledgments}

The study was financially supported by the Ministry of Education, Youth and Sports of the Czech Republic - project CENAKVA (LM2018099) and Biodiversity (CZ.02.1.01/0.0/0.0/16_025/0007370) and the Czech Science Foundation (grant number 17-19714Y), by the European Union's Horizon 2020 research and innovation program under the Marie Sklodowska-Curie grant agreement No. 642893 (IMPRESS).

\section{References}

Alavi, S. M. H., Rodina, M., Gela, D., \& Linhart, O. 2012. Sperm biology and control of reproduction in sturgeon:(I) testicular development, sperm maturation and seminal plasma characteristics. Reviews in Fish Biology and Fisheries, 22(3), 695-717.

Albers,J. L. Wildhaber M. L. and DeLonay A. J., 2013. Gonadosomatic index and fecundity of Lower Missouri and Middle Mississippi River endangered pallid sturgeon estimated using minimally invasive techniques, Journal of Applied Ichthyology, 29, 5, 968-977.

Barannikova, I. A.; Bayunova, L. V.; Semenkova, T. B., 2004: Serum levels of testosterone, 11-ketotestosterone and oestradiol-17b in three species of sturgeon during gonadal development and final maturation induced by hormonal treatment. J. Fish Biol. 64, 1330 1338.

Bemis, W. E., \& Kynard, B. (1997). Sturgeon rivers: An introduction to acipenseriform 
biogeography and life history. Environmental Biology Fish, 48, 167 - 183.

Blythe, B., Helfrich, L. A., Beal, W. E., Bosworth, B., \& Libey, G. S. (1994). Determination of sex and maturational status of striped bass (Morone saxatilis) using ultrasonic imaging. Aquaculture, 125, 175 - 184.

Bryan, M. L. Wildhaber, D. M. Papoulias, A. J. DeLonay, D. E. Tillitt and M. L. Annis, 2007. Estimation of gonad volume, fecundity, and reproductive stage of shovelnose sturgeon using sonography and endoscopy with application to the endangered pallid sturgeon, Journal of Applied Ichthyology, 23, 4, 411-419.

Chebanov, M. S., \& Galich, E. V. (2009). Ultrasound diagnostics for sturgeon broodstock management. Krasnodar, Rusko, Kuban State University, Russia: Education-South press.

Chen, X.H., Zhang, Y.Z., Wei, Q.W., Liu, Z.G., Li, L.X., Qiu, S., 2011. Observations on gonadal development of 7-11 year old Chinese sturgeon Acipenser sinensis cultured in freshwater. Journal of Applied Ichthyology, 648-650.

Colombo, R. E., Willis, P. S., \& Garvey, J. E. (2004). Use of ultrasound imaging to determine sex of shovelnose sturgeon. North American Journal of Fisheries Management, 24, 322-326.

Colombo, R. E., Garvey, J. E., \& Wills, P. S. (2007). Gonadal development and sex-specific demographics of the shovelnose sturgeon in the Middle Mississippi River. Journal of Applied Ichthyology, 23, $420-427$.

Craig J. M., Papoulias D. M., Thomas M. V., Annis M. L., Boase J. 2009. Sex assignment of lake sturgeon (Acipenser fluvescens) based on plasma sex hormone and vitellogenin levels. Journal of Applied Ichthyology 25, 60-67.

Dettlaff, T. A.; Ginsburg, A. S.; Schmalhausen, O. I., 1993: Sturgeon Fishes: Developmental Biology and Aquaculture. Springer-Verlag: Berlin, Heidelberg, New York. XIII, pp. 1 - 300 (ISBN 3-540- 54744-4).

Divers, S. J., Boone, S. S., Hoover, J. J., Boysen, K. A., Killgore, K. J., Murphy, C. E., Camus, A. C. (2009). Field endoscopy for identifying gender, reproductive stage and gonadal anomalies in free- ranging sturgeon (Scaphirhynchus) from the lower Mississippi River. Journal of Applied Ichthyology, 25, 68-74.

Doroshov, S. I., Moberg, G. P., \& Van Eenennaam, J. P. (1997). Observations on the 
reproductive cycle of cultured white sturgeon, Acipenser transmontanus. Environmental Biology Fish, 48, $265-278$.

Du, H., Zhang, X., Leng, X., Zhang, S., Luo, J., Liu, Z., Wei, Q. (2017). Gender and gonadal maturity stage identification of captive Chinese sturgeon, Acipenser sinensis, using ultrasound imagery and sex steroids. General and comparative endocrinology, 245, 36-43.

Flynn, S. R., \& Benfey, T. J. (2007). Sex differentiation and aspects of gametogenesis in shortnose sturgeon Acipenser brevirostrum Lesueur. Journal of Fish Biology, 70, 1027 1044.

Feist G, Van Eenennaam JP, Doroshov SI, Schreck CB, Schneider RP, Fitzpatrick MS (2004). Early identification of sex in cultured white sturgeon, Acipenser transmontanus, using plasma steroid levels. Aquaculture, 232: 581-590.

Golpour, A., Pš enička, M., \& Niksirat, H. (2016a). Ultrastructural localization of intracellular calcium during spermatogenesis of sterlet. (Acipenser ruthenus). Microscopy and Microanalysis, 22, 1155 - 1161.

Golpour, A., Pšenička, M., \& Niksirat, H. (2016a). Subcellular localization of calcium deposits during zebrafish (Danio rerio) oogenesis. Micron, 80.

Golpour, A., Pšenička, M., \& Niksirat, H. (2017). Subcellular distribution of calcium during spermatogenesis of zebrafish, Danio rerio. Journal of Morphology, 278(8), 1149-1159.

Henne, J. P., Ware, K. M., Wayman, W. R., Bakal, R. S., \& Horvath, A. (2006). Synchronous hermaphroditism and self-fertilization in a captive shortnose sturgeon. Transactions of the American Fisheries Society, 135, 55 - 60.

Horvath, L., Peteri, A., \& Kouril, J. (1986). Successful sterlet, Acipenser ruthenus L., propagation with synthetic LH-RH hormone. Aquaculture Research, 17, 113 - 116.

Hurvitz, A.; Jackson, K.; Degani, G.; Levavi-Sivan, B., 2007: Use of endoscopy for sex and ovarian stage determinations in Russian sturgeon (Acipenser gueldenstaedtii) grown in aquaculture. Aquaculture. 270, 158 - 166.

Jackson, K., Hurvitz, A., Din, S. Y., Goldberg, D., Pearlson, O., Degani, G., \& Levavi-Sivan, B. (2006). Anatomical, hormonal and histological descriptions of captive Russian sturgeon (Acipenser gueldenstaedtii) with intersex gonads. General Comparative Endocrinology, 148, 
$359-367$.

Jennings MJ, Claussen JE, Philipp DP. 1996. Evidence for heritable preferences for spawning habitat between two walleye populations. Trans. Am. Fish. Soc. 125(6): 978-982.

Lagler, K. F.; Bardach, J. E.; Miller, R. R.; Passino, D. R. M., 1977: Ichthyology. J. Wiley \& Sons, New York. p. 506. (ISBN 0-471- 51166-8)

Manosroi, A., Meng-Umphan, K., \& Manosroi, J. (2003). Annual sex hormonal profiles, gonad development and age determination of the Mekong giant catfish (Pangasianodon gigas, Chevey). Aquaculture Research, 34, 1379 - 1385.

Masoudifard, M., Vajhi, A. R., Moghim, M., Nazari, R. M., Naghavi, A. R., \& Sohrabnejad, M. (2011). High validity sex determination of three years old cultured beluga sturgeon (Huso huso) using ultrasonography. Journal of applied ichthyology, 27(2), 643-647.

Matsche, M. A., Rosemary, K. M., Brundage, H. M., \& O' Herron, J. C. (2013). Reproductive demographics, intersex, and altered hormone levels in shortnose sturgeon, Acipenser brevirostrum, from Delaware River, USA. Journal Applied Ichthyology, 29, 299 309.

Moghim, M., Vajihi, A. R., Veshkini, A., \& Masoudifard, M. (2002). Determination of sex and maturity in Acipenser stellatus by using ultrasonography. Journal Applied Ichthyology, $18,325-328$.

Niksirat, H., Andersson, L., Golpour, A., Chupani, L., James, P., 2017. Quantification of egg proteome changes during fertilization in sterlet Acipenser ruthenus. Biochem. Biophys. Res. Commun. 490, 189-193.

Petochi, P. Di Marco, V. Donadelli, A. Longobardi, I. Corsalini, D. Bertotto, M.G. Finoia and G. Marino (2011). Sex and reproductive stage identification of sturgeon hybrids (Acipenser naccarii $\times$ Acipenser baerii) using different tools: ultrasounds, histology and sex steroids, Journal of Applied Ichthyology, 27, 2, 637-642.

Qu, Q. Z., Sun, D. J., Wan, B. Q., \& Ma, G. J. (2010). The relationships between gonad development and sex steroid levels at different ages in Acipenser schrenckii. Journal Applied Ichthyology, 26, $1-5$.

Rzepkowska, M., Ostaszewska, T., Gibala, M., \& Roszko, M. L. (2014). Intersex gonad 
differentiation in cultured Russian (Acipenser gueldenstaedtii) and Siberian (Acipenser baerii) sturgeon. Biology of reproduction, 90 (2), 31-1.

Tan-Fermin, J. D., Ijiri, S., Ueda, H., Adachi, S., \& Yamauchi, K. (1997). Ovarian development and serum steroid hormone profiles in hatchery-bred female catfish Clarias macrocephalus Gunther during an annual reproductive cycle. Fisheries Science, 63, 867-872.

Van Eenennaam, J. P., Doroshov, S. I., Moberg, G. P., Watson, J. G., Moore, D. S., \& Linares, J. (1996). Reproductive conditions of the Atlantic Sturgeon (Acipenser oxyrinchus) in the Hudson River. Estuaries, 19, $769-777$.

Webb, M. A. H.; Feist, G. W.; Foster, E. P.; Schreck, C. B.; Fitzpatrick, M.S. (2002). Potential classification of sex and stage of gonadal maturity of wild white sturgeon using blood plasma

indicators. T. Am. Fish. Soc. 131, $132-142$.

Webb, M. A. H., Van Eenennaam, J. P., Crossman, J. A., Chapman, F. A. (2017). A practical guide for assigning sex and stage of maturity in sturgeons and paddlefish. Journal of Applied Ichthyology, 35(1), 169-186.

Wildhaber, M. L., Papoulias, D. M., Delonay, A. J., Tillitt, D. E., Bryan, J. L., Annis, M. L., \& Allert, J. A. (2005). Gender identification of shovelnose sturgeon using ultrasonic and endoscopic imagery and theapplication of the method to the pallid sturgeon. Journal of Fish Biology, 67, 114 - 132.

Williot, P., Gulyas, T. and Ceapa, C., 2002. An analogue of GnRH is effective for induction of ovulation and spermiation in farmed Siberian sturgeon Acipenser baerii Brandt. Aquaculture research, 33(9), 735-737.

Williot, P., Brun, R., Rouault, T., Pelard, M., Mercier, D., \& Ludwig, A. (2005). Artificial spawning in cultured sterlet sturgeon, Acipenser ruthenus L., with special emphasis on hermaphrodites. Aquaculture, 246, 263 - 273. 

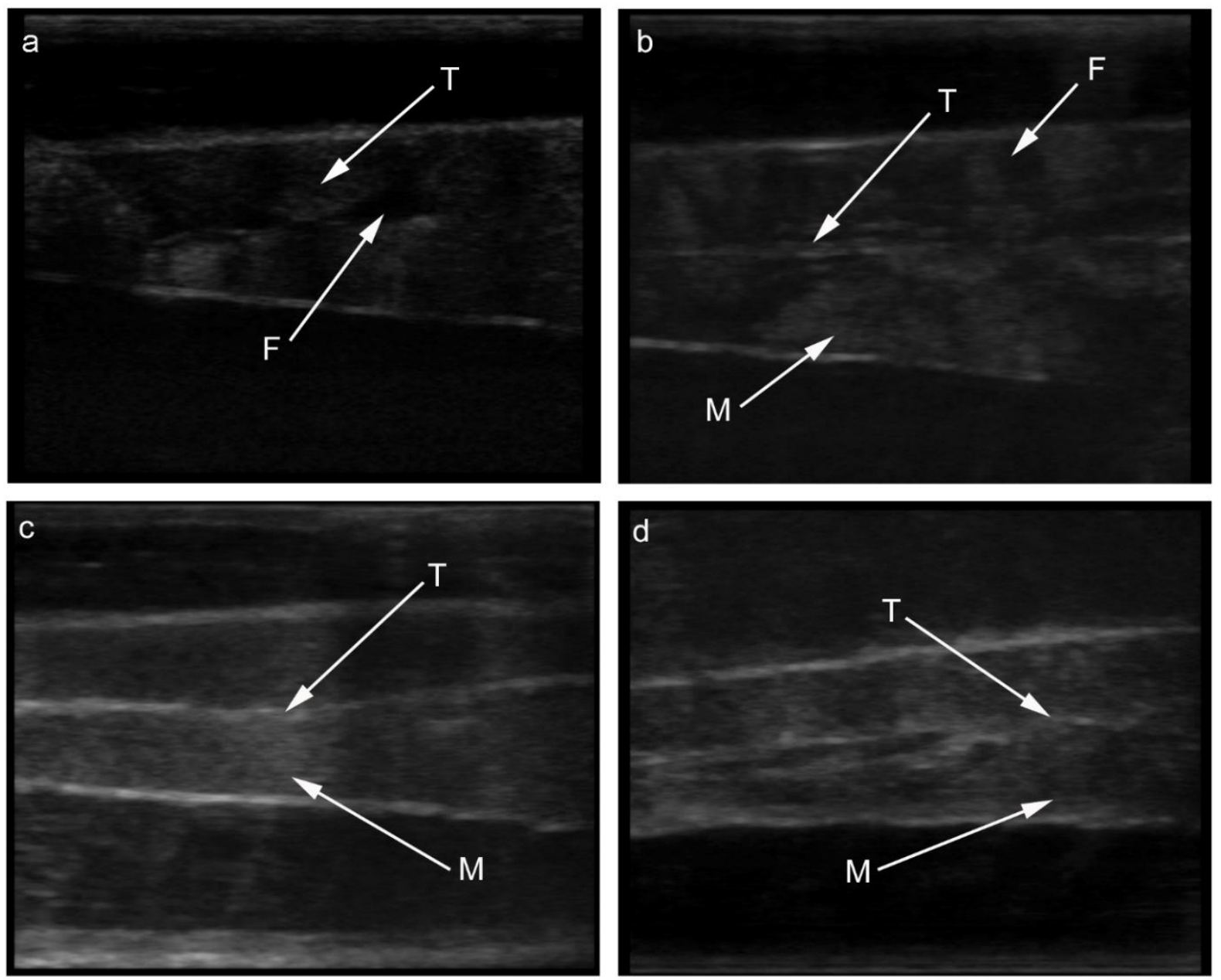

Fig. 1. Ultrasound images taken from testes of sterlet during annual cycle: (a) undeveloped testis in autumn (resting phase), (b) testis in pre-spawning state in winter, (c) fully mature testis in spring and (d) testis in post-spawning state. F; fat tissue, M; muscle, T; testis. 


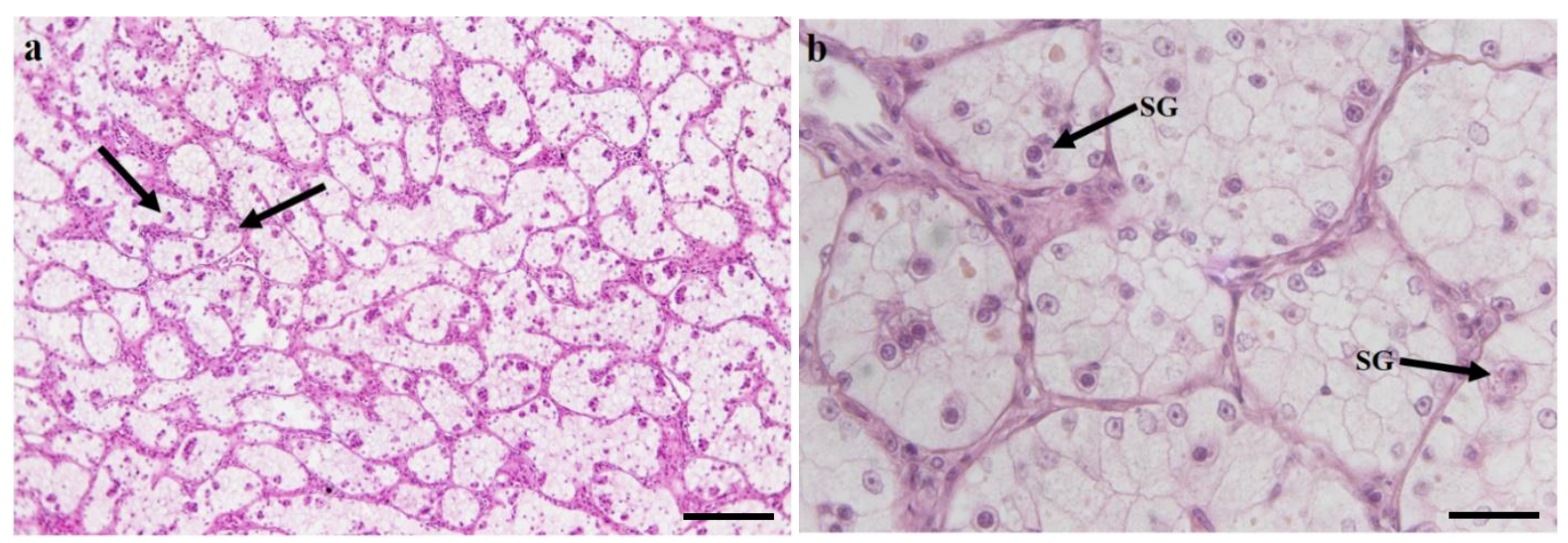

Fig. 2. Transverse section of the sterlet testis during autumn (resting phase) shows the onset of testicular meiosis. a; arrows show spermatogonia type A enclosed in cysts (scale bar 50 $\mu \mathrm{m}) \mathrm{b}$; arrows show proliferation of spermatogonia type A (scale bar $100 \mu \mathrm{m}$ ). H\&E staining was used for histology sections. 


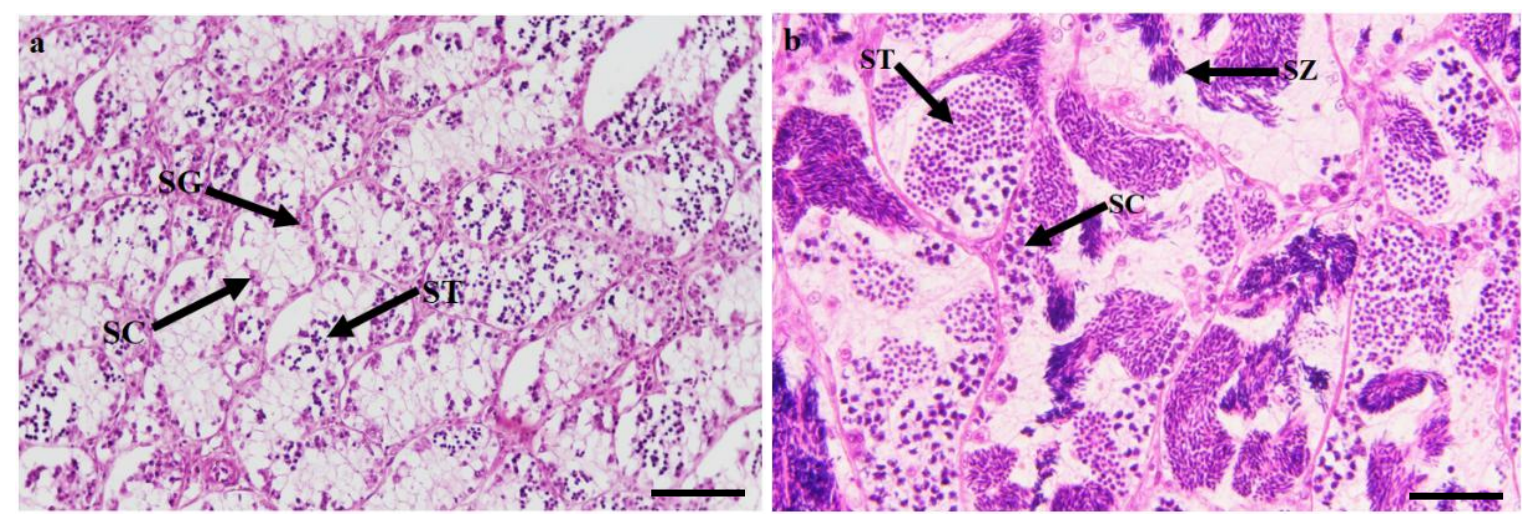

Fig. 3. Transverse section of the sterlet testis during winter (pre-spawning phase) exhibiting ongoing meiosis. a; early-spermatogenesis (meiosis); arrows show developing spermatocyte and spermatid in the clusters, b; late meiosis and spermiogenesis exhibit the cysts with developing spermatogenic cells and spermatozoa. H\&E staining was used for histology sections. SG - spermatogonia, SC - spermatocyte, ST - spermatid, SZ - spermatozoa. All scale bars are $100 \mu \mathrm{m}$.

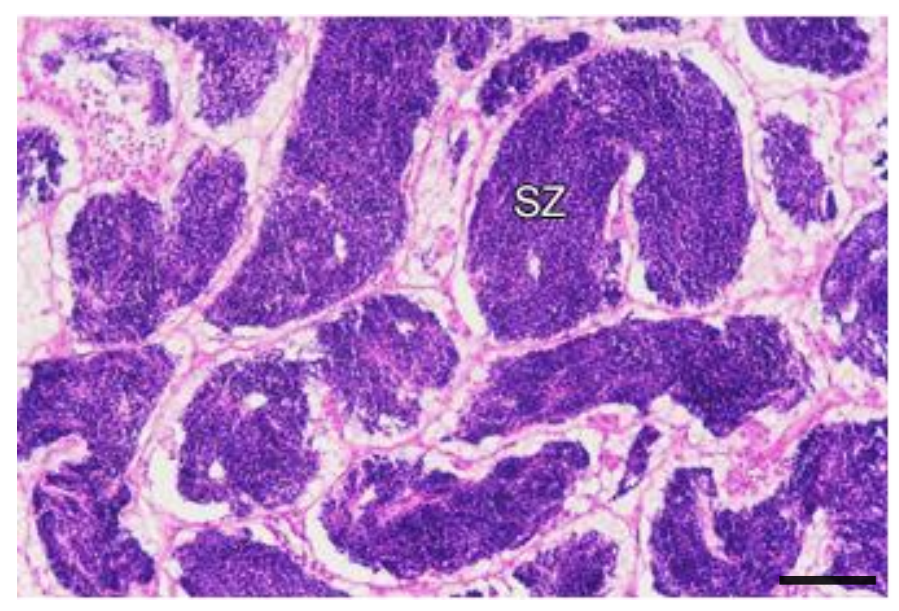

Fig. 4. Transverse section of the sterlet testis during spring (spawning phase) shows cysts with differentiated spermatozoa. H\&E staining was used for histology sections. SZ; spermatozoa. Scale bar is $100 \mu \mathrm{m}$. 


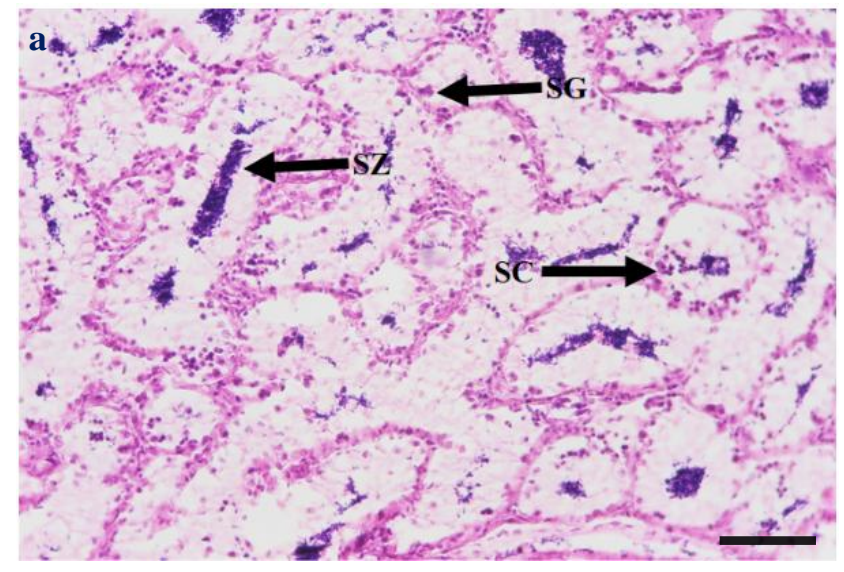

Fig. 5 .

Transver

se

section

of the

sterlet

testis

during

summer

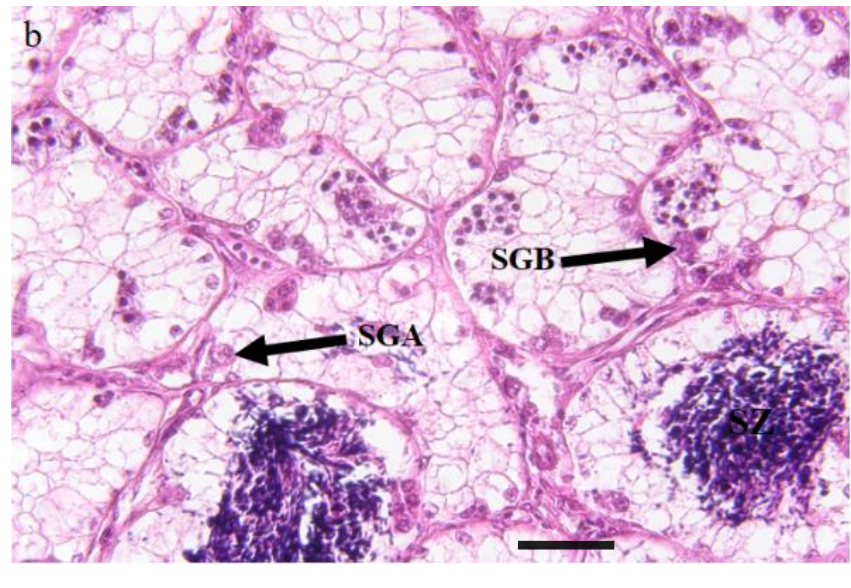

(post-spawning phase) showing the absorption of unshed spermatozoa. a; spermatogonia type A located along the periphery of the lobule (scale bar $50 \mu \mathrm{m}$ ), b; Higher magnification shows the reabsorbing unshed spermatozoa and remained meiotic cells (scale bar $100 \mu \mathrm{m}$ ). H\&E staining was used for histology sections. CS, Cyst; SGA, Spermatogonia type A; SGB, Spermatogonia type B; SZ, spermatozoa.
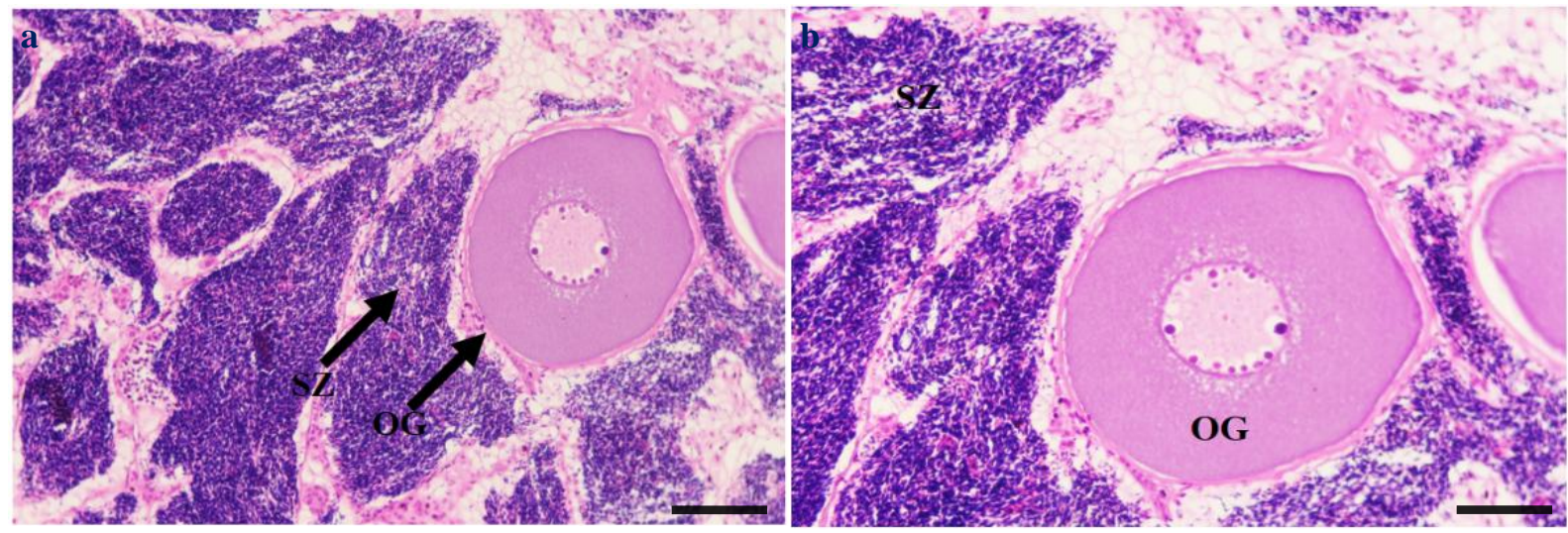

Fig. 6. Transverse section of sterlet intersex gonad (testis-ova). a; showing a pre-vitellogenic oocyte close to testicular lobules containing spermatozoa at the interface between ovary and testis (scale bar $50 \mu \mathrm{m}$ ), b; Higher magnification showing the close proximity between oocyte and spermatozoa (scale bar $200 \mu \mathrm{m}$ ). H\&E staining was used for histology sections. OC: Oocyte, SZ: Spermatozoa. 
Table 1 Monthly growth parameters and gonadosomatic indices of sterlet males $(n=3)$. Data are mean $\pm \mathrm{SD}$.

\begin{tabular}{llccccc}
\hline Years & $\begin{array}{l}\text { Developmental } \\
\text { Stages }\end{array}$ & Months & Weight & Length & $\begin{array}{c}\text { Gonadosomatic } \\
\text { index (\%) }\end{array}$ & Temperature \\
\hline 2014 & $\begin{array}{l}\text { Post-spawning } \\
\text { phase }\end{array}$ & July & $1016 \pm 27.6$ & $64.3 \pm 4.8$ & $1.44 \pm 0.1$ & $24{ }^{\circ} \mathrm{C}$ \\
$\begin{array}{l}\text { Post-spawning } \\
\text { phase } \\
\text { Post-spawning } \\
\text { phase }\end{array}$ & August & $1023 \pm 28.4$ & $64.6 \pm 6.2$ & $1.28 \pm 0.2$ & $22{ }^{\circ} \mathrm{C}$ \\
& September & $1023 \pm 25.8$ & $64.3 \pm 5.2$ & $1.16 \pm 0.3$ & $20^{\circ} \mathrm{C}$ \\
\hline
\end{tabular}




\begin{tabular}{|c|c|c|c|c|c|c|}
\hline & Resting phase & October & $1040 \pm 19.5$ & $58.2 \pm 7.3$ & $1.3 \pm 0.1$ & $15^{\circ} \mathrm{C}$ \\
\hline & Resting phase & Novembe & $1124.6 \pm 16.3$ & $60.3 \pm 3.9$ & $1.02 \pm 0.02$ & $11^{\circ} \mathrm{C}$ \\
\hline Years & Defelopmental stage: & Decembe & Month $760 \pm 17.5$ S $(\%)$ & $61 \pm 4.6(\%)$ & $1.01 \pm 0.06$ & $\mathrm{SZ}_{11}(\%)$ \\
\hline \multirow[t]{6}{*}{$\begin{array}{c}2014 \\
2015\end{array}$} & Postpreaspaininghase & \multirow{2}{*}{ January } & $\begin{array}{l}\text { July } \\
1166.6 \pm 20.8\end{array}$ & $.7 \underset{58.9 \pm 5.7}{1.2 \pm 0.1}$ & $\begin{array}{l}0.3 \pm 0.1 \\
1.83 \pm 0.1\end{array}$ & $\begin{array}{l}12.3 \pm 0.05 \\
10^{\circ} \mathrm{C}\end{array}$ \\
\hline & $\begin{array}{l}\text { phase } \\
\text { Post-spawning phase } \\
\text { Pre-spawning }\end{array}$ & & August $\quad 87 \pm 2$ & $1.2 \pm 0.2$ & $0.28 \pm 0.01$ & $11.2 \pm 0.03$ \\
\hline & $\begin{array}{c}\text { Pre-spawning } \\
\text { Postpspsewning phase }\end{array}$ & February & $\begin{array}{c}1066.6 \pm 27.5 \\
\text { September }\end{array}$ & $60.7 \pm 3.4+0.2$ & $\begin{array}{l}2.04 \pm 0.2 \\
0.18 \pm 0.01\end{array}$ & $\begin{array}{l}12^{\circ} \mathrm{C} \\
9.8^{\circ} \pm 0.07\end{array}$ \\
\hline & $\begin{array}{l}\text { Pre-spawning } \\
\text { Resting phase } \\
\text { phase }\end{array}$ & March & \multicolumn{2}{|c|}{ Octobe $850 \pm 3394.7 \pm 1.553 .3 \pm 4.8 \pm 0.1$} & $1.953 \pm \pm 00.1$ & $0.53 \pm 0.02$ \\
\hline & $\begin{array}{l}\text { ReStilingingsse } \\
\text { phase }\end{array}$ & April & \multicolumn{2}{|c|}{ Novemger $\pm 23.5 .5 \pm 1.452 .5 \pm 4.8 \pm 0.3$} & $1.98 \pm+9.30 .01$ & $0.97+0.01$ \\
\hline & Restipgrinhase & \multirow{2}{*}{ May } & $\begin{array}{c}\text { December } \\
863.3 \pm 25.9\end{array}$ & $\begin{aligned} & 6.5 \pm 0.5 \\
54.8 \pm & 6.5\end{aligned}$ & $\begin{array}{l}1.01 \pm 0.06 \\
0.8 \pm 0.1\end{array}$ & $\begin{array}{l}0.72 \pm 0.02 \\
16^{\circ} \mathrm{C}\end{array}$ \\
\hline \multirow[t]{2}{*}{2015} & $\begin{array}{l}\text { phase } \\
\text { Pre-spawning phase }\end{array}$ & & $\begin{array}{ll}\text { January } & 7.1 \pm 0.09\end{array}$ & $9 \quad 42.3 \pm 0.15$ & $35.6 \pm 0.2$ & $16.6 \pm 0.4$ \\
\hline & Pre-Bpasenning phase & June & \multicolumn{2}{|c|}{ 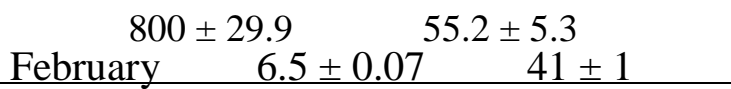 } & $\begin{array}{l}0.79 \pm 0.2 \\
\quad 34.4 \pm 0.6\end{array}$ & $\begin{array}{c}19^{\circ} \mathrm{C} \\
18.2 \pm 0.2\end{array}$ \\
\hline
\end{tabular}

Table 2 Monthly percentage of spermatogonia (SG), spermatocytes (SC), spermatids (ST) and spermatozoa (SZ) during different phases of the reproductive cycle in sterlet. 
Pre-spawning phase

$$
\text { March }
$$$$
6.3 \pm 0.09
$$

$39.7 \pm 1.1$

$34.5 \pm 0.2$

$17.7 \pm 0.5$

Spawning phase

April

$0.02 \pm 0.02$

$1.5 \pm 0.1$

$5.4 \pm 0.1$

$92.5 \pm 0.3$

Spawning phase

May

$0.01 \pm 0.02$

$1.84 \pm 0.01$

$6.8 \pm 0.1$

$91.1 \pm 0.2$

Spawning phase

June

$0.03 \pm 0.01$

$1.23 \pm 0.3$

$4.7 \pm 0.08$

$93.2 \pm 0.6$

Values represent mean \pm SD of observation based on 15 photos taken from histology for each month. 